\title{
THE IMPACT OF LEARNING STARTS WITH A QUESTION METHOD TO LEARNING OUTCOMES IN (SOCIAL STUDIES)
}

\author{
Takiddin, Resty Meidiana \\ Departement of Islamic Primary School Teacher Education of Faculty of Tarbiya and \\ Teacher Training State Islamic University of Syarif Hidayatullah Jakarta \\ Email: Takiddin@gmail.com, restymeidiana05@gmail.com
}

Naskah diterima : 7 Agustus 2017, direvisi : 31 Agustus 2017 , disetujui : 15 September 2017

\begin{abstract}
This research aims to know the Effect of Learning Starts With A Question (LSQ) Method to Learning Outcomes of IPS (Social Studies) Subject at MIN 15 Bintaro. The method used in this research is quasi experiment with research design of two group randomized subject pretest and posttest. This research was conducted at MIN 15 Bintaro on 21 April - 12 May 2014. The sampling technique in this study used cluster random sampling. The instrument of this research is a test (multiple choice) which amounts to 25 multiple choice questions. To measure the validity of the data reseacher used Annates Program. After hypothesis testing using technique Paired Sample T-Test obtained t count equal to 0,034 at significance level $<0,05$, thus, H1 accepted and $\mathrm{H} 0$ rejected because $0,034<0,05$, so it can be concluded that there is influence of Learning Starts With A Question (LSQ) method to Learning Outcomes of IPS (Social Studies) Subject.
\end{abstract}

Keywords : Learning Starts With A Quesion (LSQ), Learning outcomes, IPS (Social Studies)

Pengutipan: Takiddin \& Resty Meidiana. (2017). The Impact of Learning Starts with a Question Method to Learning Outcomes in (SOcial Studies). JMIE: Journal of Madrasah Ibtidaiyah Education, 1(2), 2017, 172-179. jmie.v1i2.37. 


\section{Background of the Study}

Teachers should be able to impenetrate the 'students world' in the learning process through learning planning. In this case, the ability of teachers to impenetrate the 'students world' both before and during the course of learning, so that it can realize successful learning because it helps teachers to complete the learning process, more attached and more meaningful with satisfactory learning outcomes.

Based on the an interview with the IPS (social studies) subject teacher at MIN 15 Bintaro, it was observed that the learning methods commonly used here are the sociodrama, lecture, discussion and question and answer, but the most commonly used is the lecture method. Consequently, based on the an interview with student grade IV A and IV B at MIN 15 Bintaro, it can be illustrated that some students like IPS (Social Studies) subject and more students do not like IPS (Social Studies) because they assume that IPS (Social Studies) is a subject full of saturated memorizing the subject matter. This resulted the students' learning outcomes on IPS (social studies) subject to be low. The average of IPS (social studies) grade Student class IV in MIN 15 Bintaro is 55 with the Minimum Criteria of Mastery Learning (abbreviated KKM in Indonesia) for IPS (soical studies) is 65.

Therefore it is important to apply vary and innovative learning methods in order to attract students interest to follow the IPS (soical studies) learning process. One of the learning method that can be applied by teacher in IPS (social studies) learning is Learning Starts With A Question (LSQ) method. Learning Starts With A Question method is a method that invites students to be able to ask questions and find the answers to the questions they ask by discussing with their group so they will master the subject matter they learn more. Before they ask questions, they must first read and understand the subject matter that is given by the teacher so that they can bring up the questions that they want to ask from the subject matter that they do not understand yet.

Learning Starts With A Question method is expected to optimize the learning process of IPS (social studies) in the classroom because with this method students are required to understand the subject matter that provided by the teacher by discussing with their group. In addition, students are also asked to make some questions for the subject matter that they have not understood in such a way that students are expected to improve learning outcomes in social studies subject. Based on the above explanation, this study aims to determine the effect of Learning Starts With A Question (LSQ) method to the student learning outcomes on IPS (Social Stidues) subject.

\section{Theoretical Framework}

\section{Learning Starts With A Question Method}

\section{What is Learning Starts With A Question (LSQ) Method?}

Suryo Budi Susanto (2013: 432) states that learning starts with a question method is a method where students are directed to self-study by making questions based on the reading material that given by the teacher. Then the students try to find answers from these questions through discussions with other students and teachers ready to help if students find the difficulties to find the answers. Hamruni (2009: 276) reveals that Learning Starts With A Question (LSQ) method is a learning method where the learning process of 
something new will be more effective if the students are active in asking questions before they get the expalanation about the subject matter from the teacher.

\section{The Steps of Learning Starts with a Question Method}

Agus Suprijono (2009: 112) stated that the steps of Learning Starts With A Question (LSQ) method are as follows:

1) Select the appropriate reading material then share it with the students. By choosing a particular topic or chapter from a textbook. It will be better if the reading material contains the general information or readings that allow the opportunity to be interpreted differently.

2) Ask students to study the reading by themselves or with friends.

3) Ask students to mark on passages they do not understand. Encourage them to mark as many as possible. If time permits, combine the learning partner (student) with another partner, then ask them to discuss unknown points that have been marked.

4) In a pair or small group, ask students to write down the questions about the reading material they have read.

5) Gather the questions the students have written.

6) Present the subject matter by answering these questions.

\section{Learning Starts With A Question Adventages and Weaknesses}

The advantages and weaknesses in Learning Starts With A Question Method are (Sudrajat in Hamruni, 2009) as follows:

1) The Advantages of Learning Starts With A Question Method

a) Students are better prepared to start the lesson, because they have first studied the subject matter so they have a little description and more understand after getting additional explanation from the teacher;

b) Students become actively inquiring;

c) The subject matter may be longer remembered by students;

d) When students learn to ask questions, their intelligence is more sharpened;

e) Encourage the growth of students courage to openly express their opinions and broaden students insight through opinion exchange;

f) Students learn to solve their own problems and work together among clever and less clever students.

g) allow the teacher to know which students learning and and which students do not learn;

2) Learning Starts With A Question (LSQ) Method Weaknesses

a) It takes a long time if many questions are asked by students

b) If teachers give an opportunity to other students who do not learn or do not master the subject matter to answer, the questions or answers can wander around; 
c) apathy for students who are not accustomed to speak in a forum

d) Require students to have sufficient background on the topics or issues that discussed.

\section{Learning Outcomes}

\section{The Definition of Learning Outcomes}

Nana Sudjana (2001: 22) stated that learning outcomes is the abilities that students have after receiving their learning experience. Learning outcomes intended can be students' understanding of the lessons that have been given, or can be an analysis of a thing, and it can also in the form of problem solving that done by students to a certain thing. The same opinion is also expressed by Ngalim Purwanto (1994: 33) stated that "Learning outcomes is the results of lessons that given by teachers to students within a certain time." Learning outcomes can be test, daily test, or final evaluation. Gredler in Ibrahim (2009: 111) stated that "Learning outcomes is a new response (behavior)." Meanwhile, according to Hamalik (Jamalong, 2012) Learning outcomes is a change of subjects behavior that include cognitive, affective, and psychomotor abilities in certain situations due to repeated experience.

Agus Suprijono (2009: 6-7) stated that, "Learning outcomes include cognitive, affective, and psychomotor abilities. Each ability includes:"

1) Cognitive domain includes; knowledge, omprehension, application, analysis, synthesis, and evaluation.

2) Afective domain consists of: receiving, responding, valuing, organization, characterization.

3) psychomotor domain consists of: including productive, technical, physical, social, and intellectual abilities

\section{The Factors that Affecting Learning Outcomes}

Basically, student learning outcomes in learning activities at school is not only caused by student's intelligence, but also there are other things that become the determinant factors that can not be separated in achieving student learning success. Ngalim Purwanto (1994: 107) argues that these factors can be divided into two kinds, namely:

1) External factors can be classified into two, namely environmental factors and instrumental factors. The categorized environmental factors include: natural and social. While the categorized instrumental factors include: curriculum / lesson materials, teachers, facilities, and administration/management.

2) Internal factors can be classified into two, namely physiological factors and psychological factors. Physiologically categorized include: physical condition and condition of the five senses. While the categorized psychological factors include: talent, interest, intelligence, motivation and cognitive abilities.

\section{IPS (Social Studies)}

The term of Social Studies, abbreviated as IPS in Indonesia, is the name of the 
subject at primary and secondary level or the name of the departement in university which is identical to the term "social studies" in the schoole curriculum in other countries particularly in Western countries such as Australia and the United States (Sapriya, 2009:19). Social Studies is a subject that examines a set of events, facts, concepts, and generalizations related to social and civic issues (Arnie Fajar, 2002: 110). is an integration of various branches of social sciences such as: sociology, history, geography, economics, politics, law and culture. IPS (social studies) is also formulated on the basis of reality and social phenomena that embody an interdisciplinary approach of social sciences aspects and branches (Trianto, 2007: 124).

So IPS (social studies) is a subject that studies about social life. IPS also discusses the relationship between humans and their environment. The community environment where students grow and develop as part of society, faced to various problems that exist and occur in the environment. IPS (social studies) also helps students to solve the problems they face, so that it will make them more understand their social community environment.

\section{Social Studies Learning Purposes}

The purposes of Social Studies Subject are:

1) Teaching basic concept of sociology, geography, economic, history, and civic education through pedagogical and psychological approach;

2) Developing critical and creative thinking skills, inquiry, problem solving, and social skills;

3) Building the commitment and awareness of social values and humanity;

4) Improving the ability to cooperate and compete in compex society, nationally and globally (Arnie Fajar, 2002: 110-111).

The social studies main purpose is to develop students potency to delicate of social problems that occures in the society, having positive mentality to solve all of the inequality that occured, and social problems, and they ingenious to overcome the daily problems both afflict him and society (Trianto, 2007:176).

Based on the the experts opinions above, it can be stated that the purpose of social studies is to educate and to prepare students basic competence in developing themselves based on their talents, interests, potentialities, and their environments, and prepare students competence to continue their education to higher education.

\section{Research Methodology}

Research methodology in this research is experimental quasi. Reseacher applied Learning Starts With A Question (LSQ) method to enhance the students IPS (social studies) learning outcomes by comparing the social studies learning outcomes between students that learn using Learning Starts With A Question (LSQ) Method as an experimental class and students who did not learn using Learning Starts With A Question (LSQ) method as a cotroll class. Research design in this research is Two Group Randomized Subjects Pretest and Posttest design. 
Sugiyono (2008:80) stated that population is a generalization area that consists of objects or subjects which has certain qualities and characteristics that set by the researchers to be studied and then creat the conclusions. The population in this research is all of the students Grade IV MIN 15 Bintaro, academic year 2013/2014 samount 3 classes.

The sampling technique used in this research is purposive sampling, this sampling technique is selected based on the researchers consideration. Sample determination is done by selecting two classes that have the same character. The class chosen as the experimental class in this research is the class IV A which amount 38 students, while the class selected as the control class is class IV B with 38 students.

\section{Result and Discussion}

Based on the analisys to IPS (social studies) learning outcomes grade IV second semester of MIN 15 Bintaro that has been devied into two groups, experiment class and control class. Both classes have homogeneous data. It means that the data have normal distribution and variants and were not different significantly. So this indicates that the initial condition of the students before being treated is still in the same condition The experimental group is the class treated with the Learning Starts With A Question (LSQ) method and the control group is a class that is not treated with the Learning Starts With A Question (LSQ) method. At the end of the meeting was conducted a test of learning outcomes (posttest) to the experimental class and control class. This research is conducted in 4 (four) meetings.

At the first meeting, the students were still confused in learning the subject matters which provided by the teacher. Students find the difficulties to find the questions they will ask, and how to answer and discuss the questions they ask. Students are accustomed to listen and write what teachers write in front of the class, and lack of interaction between teacher and students so that they are not used to express or asking questions if there is something they do not understand yet.

During the secend meeting the group representatives were asked to present their discussion in front of the class. Students were still visibly shy and difficult to convey their group discussions in front of class, so the teacher should force some group representatives to ask the questions and present their discussions with the group. In addition, the other groups were also less attention and make a joke with friends so, when they were asked to respond the other group presentation, they did not understand how to respond it well. Thus, the teacher tried to direct and guid them to be able to respond the other group presentation.

At the next meeting students abilities in learning prosess getting better. Students have begun to understand the method of learning applied by the teacher, they were able to find questions that they do not understand from the teaching materials that the teacher give and discuss the answer of the question. Students were more daring to present their group discussion in front of the class and the other students did not hesitate in expressing their opinions.

It is different to the control group that taught without Learning Starts with a Qusetion (LSQ), the students were more passive and just listen and record what the 
teacher presented and wrote on the white board. When the teacher explained the students more chatting and joking with their friends. Only a few students took notice of the explanations that the teacher gives.

From the description above it can be seen that there is a differentiation of proactiveness between students were taught using Learning Starts With A Question (LSQ) method with students who were not taught using Learning Starts With A Question (LSQ) method.

From the result of research and data processing, it can be seen that the IPS (social studies) learning outcomes experimental group is better than the control group learning outcomes. This result is shown by pretest average value of experimental group is 61,8947 and after using Learning Starts With A Question (LSQ) method, experimental group posttest value increased to 76.6842. While the average pretest of the control group was 60.4211, and the control group's posttest score increased to 71.6842. Based on the calculation of the average value, the experimental group test results increased by $14.79 \%$, while the control group test results increased by $11.26 \%$.

Based on the above calculation, it can be stated that the Learning Starts With A Question (LSQ) method in fourth grade students of MIN 15 Bintaro conducted on the experimental group showed a positive effect. By using Learning Starts With A Question (LSQ) method in the experimental class the students were more motivated and their learning interest is greater than the control group. So it can be stated that Learning Starts With A Question (LSQ) method has a positive effect on the process and students learning outcomes of IPS (social studies) grade IV MIN 15 Bintaro.

\section{Conclusion}

The experimental class learning outcomes using Learning Starts With A Question (LSQ) method is better than control class that learn without using Learning Starts With A Question (LSQ) method. This result is obtained through t-test or hypothesis test that was conducted on posttest value of both groups, experiment and control using SPSS 16 for Windows that yielded a probability value on significance (2-tailed) is 0.034 . Thus, H0 is rejected and $\mathrm{H} 1$ is accepted, since $\mathrm{H} 0$ is rejected if $\varrho<0.05$. From the data show that $0.034<0.05$. So, it can be concluded that there is an influence of learning starts with a question (LSQ) to students Social Studies Learning outcomes Grade IV MIN 15 Bintaro.

\section{References}

Agus Suprijono. (2009). Cooperative Learning Teori dan aplikasi PAIKEM. Yogyakarta: Pustaka Pelajar.

Arikunto, Suharsimi. (2012). Dasar-dasar Evaluasi Pendidikan. Jakarta: Bumi Aksara.

Fajar, Arnie. (2002). Portofolio Dalam Pelajaran IPS. Bandung: PT Remaja Rosdakarya.

Hamruni. (2009). Strategi dan Model-model Pembelajaran aktif-Menyenangkan, Yogyakarta: Fakultas Tarbiyah UIN Sunan Kalijaga. Skripsi. Tidak dipublikasikan. Nana Sudjana. (2001). Penilaian Hasil Proses Belajar Mengajar. Bandung: PT Remaja Rosdakarya.

Ibrahim, Nurdin . (2009). Pengaruh Pembelajaran Berbantuan Komputer Terbadap Hasil Belajar. Jurnal Pendidikan dan Kebudayaan, No. 1. 
Jamalong, Ahmad. (2012). Meningkatkan Hasil Belajar Siswa Melalui Model Kooperatif NHT di Kelas X SMA Negeri 1 Beduai Kabupaten Sanggau, Jurnal Pendidikan \& Kebudayaan, No. 4, Desember 2012.Purwanto, Ngalim. (1994). Prinsip-prinsip dan Tehnik Evaluasi Pengajaran. Bandung:PT Remaja Rosdakarya.

Sapriya. (2009). Pendidikan IPS. Bandung: PT Remaja Rosdakarya.

Sapriya, Dadang Sundawa, dan Iin Siti Masyitoh. (2006). Pembelajaran dan Evaluasi Hasil Belajar IPS. Bandung: UPI PRESS.

S. Margono. (2013). Metode Penelitian Pendidikan. Jakarta: Rineka Cipta.

Sugiyono. (2008). Metode Penelitian Kuantitatif, Kualitatif, dan R\&D. Bandung: Alfabeta.

Susanto, Budi, Suryo. (2013). Pengaruh Strategi Learning Starts With A Question Terhadap Hasil Belajar Siswa Pada Standar Kompetensi Memahami Sifat Dasar Sinyal Audio di SMKNegeri 2 Surabaya. Jurnal Pendidikan Teknik Elektro, No. 1 Tahun 2013.

Syaiful Bahri Djamarah. (2008). Psikologi Belajar. Jakarta: PT Rineka Cipta.

Trianto. (2007). Model Pembelajaran Terpadu Dalam Teori dan Praktek. Jakarta: Prestasi Pustaka. 